INTERNATIONAL HIGHER EDUCATION Number 75 Spring 2014

Pages 19-21

\title{
Canada's Immigration Policies to Attract International Students
}

\author{
ANITA GOPAL
}

Anita Gopal is a researcher at Queen's University in Kingston, Ontario, Canada. E-mail: anita.gopal@gmail.com.

Universities around the world engage in an intense competition to compete in the knowledge economy due to globalization. This situation has served as a catalyst for Canada to engage in immigration strategies and initiatives designed to attract and recruit international students. As also an urgent need for highly skilled individuals, since there is a concern that once baby boomers retire, there will be severe labor shortages, which will have negative implications for Canada's growth and nation building. Attracting and retaining international students is a way to boost Canada's economy, while promoting a welcoming international landscape. According to Citizenship and Immigration Canada, the government's priority is to seek highly skilled individuals (e.g., India, China) who are likely to succeed in Canada and to promote its economic growth, longterm prosperity, and global competitiveness. International students, who pursue their studies in Canada, are an ideal population because they would have already been integrated into Canadian society.

Recognizing that international students are vital to Canada's growth, the Citizenship and Immigration Canada has set out to transform Canada's 
immigration system as one that is faster, more flexible, and tailored to students' needs-a major distinguishing factor from other countries. Therefore, new immigration policies and programs have been specifically created to make it easier for international students to study, work, and become permanent residents in Canada, especially for graduate students. For instance, international students are permitted to work on and off campus, without a work permit to a maximum of 20 hours per week. They can also apply for a Post-Graduation Work Permit, a three-year open work permit, which enables students to work for any Canadian employer in any industry. International graduate students can apply to the Provincial Nomination Program for permanent residence in Canada—during their master's or doctoral program or upon completion of their degree.

Canadian universities are also interested in gaining its "market share" of the best and brightest international students in science and technology and acquiring a competitive advantage over countries such as the United States and the United Kingdom, which are major destination countries for international students. Moreover, international students generate a substantial amount of revenue to Canada. According to a report conducted by the Department of Foreign Affairs and International Trade, in 2010, international students in Canada spent in excess of Can $\$ 7.7$ billion on tuition, accommodation and discretionary spending (up from Can $\$ 6.5$ billion in 2008). More than Can $\$ 6.9$ billion of this revenue was generated by the 218,200 long-term international students in Canada. The report also indicated that the revenue from international student spending in Canada is greater than the Canadian export value of unwrought aluminum (Can $\$ 6$ billion), or helicopters, airplanes, and spacecraft (Can $\$ 6.9$ billion). 


\section{IMmigRation Policies in The United STATes}

After the $9 / 11$ attacks, the United States' traditional open-door policy for international students was curtailed. Immigration policies have become more stringent due to the government's tightening of the border and strict visa requirements. As outlined in the 2013 International Student Mobility Trends report, the United States has been slow to revisit their immigration and visa policies. However, it still remains the top choice for international students to study due to its prestigious universities' degree programs.

Unlike Canada's multiple pathways to work and become permanent residents, international students enrolled in academic programs in the United States holding F-1 student visas can only gain work experience by applying for Optional Practical Training, a temporary employment program that is related to a student's major area of study. Students can apply to this program after completing one academic year of their studies and could receive up to a total of 12 months of practical training, either before and/or after completing their program. Students in fields such as science, technology, engineering, and mathematics are entitled to a 17 month extension. If students are eligible to change their student status (F-1 visa status), they must apply for an H-1B visa (a nonimmigrant temporary working visa), which allows the holder to work in the United States for up to six years. However, the student must first have a job offer and an employer who is willing to file a "petition" or request with the Immigration and Naturalization Services. 


\section{Changes in the United Kingdom}

Recent government policies in the United Kingdom have imposed tighter international student visa restrictions-affecting entry requirements, services available to students during their studies, and work options available to students after completing their program. According to The Funding Environment for Universities report, reforms to student immigration to the United Kingdom and to student visa applications will come into effect in the 2013/2014 academic year. This includes tougher, English-language skills requirements and an increase in the amount of credibility check interviews in terms of students' immigration history, education background, and financial support. The government has also discontinued the Post Study Work scheme. These changes make it more challenging for international students from non-European countries to qualify for a work permit to stay in the United Kingdom after graduation. Such policies do not promote permanent residence, postgraduate or labor retention, and have mainly impacted overseas recruitment of students from India, Pakistan, and Saudi Arabia.

\section{FUtURE DiRections}

While Canada is focusing on competing with the United States and the United Kingdom for its share of international students through its flexible immigration policies and pathways, higher education institutions have yet to come up with a strategy to manage highly skilled migration. Canadian universities are being urged by federal policies to double international student enrollment from 240,000 in 2011 to 450,000 by the year 2022. If Canada will compete for its share of international students, organizational mechanisms must be implemented to 
prepare for this shift in recruitment. Concurrently, Canadian higher education institutions must develop competitive programs and degrees to meet the needs of the target student population and provide access to relevant institutional resources (e.g., faculty, research funding, student services, library resources, etc.). Otherwise, how productive are immigration policies, if inadequate resources are available at Canadian universities, to support international students? As of yet, there are no official national strategies in place to prepare for and manage these changes.

It is clear that Canada has primarily focused on its own national interest of attracting international students to remedy its skilled labor shortages. As a result, it has not paid much attention to the problem of brain drain and the overarching consequences of luring highly talented students from developing nations to developed Western nations. For instance, the United Nations Development Program points out that brain drain has caused approximately 100,000 of the best and brightest Indian professionals to move to North America each year, which is estimated to be a $\$ 2$ billion loss for India. As Canada continues to siphon intellectual capital from developing regions, it has neglected to think about its moral responsibility to these nations or how it could be harming their economic growth and well-being. Meanwhile, it is unclear as how developing nations will recover the loss of their human capital. 